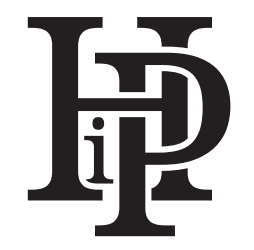

Historia i Polityka

$\operatorname{Nr} 35(42) / 2021$, ss. $165-167$

www.hip.umk.pl (c) (1) $\odot$

ISSN 1899-5160, e-ISSN 2391-7652

DOI: http://dx.doi.org/10.12775/HiP.2021.010

Michał DAHL

Uniwersytet Mikołaja Kopernika, Wydział Nauk o Polityce i Bezpieczeństwie, Toruń, Polska

\title{
Jabin T. Jacob, Hoang The Anh (red.). China's Search for 'National Rejuvenation'. Domestic and Foreign Policies under Xi Jinping, Palgrave Macmillan, Singapore 2020,
} ss. 237

Monografia zatytułowana China's Search for 'National Rejuvenation'. Domestic and Foreign Policies under Xi Jinping, przygotowana pod redakcją naukową Jabina $\mathrm{T}$. Jacoba i Hoang The Anha, dotyczy problematyki stosunkowo często podnoszonej w badaniach nad współczesnymi stosunkami międzynarodowymi. Przemiany dokonujące się w Chińskiej Republice Ludowej (ChRL) już od momentu jej proklamacji 1 października 1949 r., przede wszystkim jednak po wdrożeniu programu "reform i otwarcia na świat” (gaige, kaifang; Góralczyk, 2021, s. 17), stanowią źródło inspiracji i stają się przyczynkiem do dyskusji i analiz dotyczących nie tylko przyszłości Państwa Środka, ale i kierunków przemian współczesnego ładu w wymiarze globalnym. Tytuł książki bezpośrednio nawiązuje do koncepcji „wielkiego renesansu narodu chińskiego" (Zhonghua minzu weida fuxing), zaliczanego - wraz z planem przekształcenia społeczeństwa chińskiego w „społeczeństwo umiarkowanego dobrobytu” (xiaokang shehui) - do zaprezentowanych przez przewodniczącego ChRL Xi Jinpinga „dwóch celów na stulecie" (liangge yi bai nian). Wdrożenie wspomnianych dwóch celów miało w zamyśle chińskich decydentów umożliwić realizację koncepcji „chińskiego snu” (Zhongguo meng). Koncepcja ta stała się motywem przyświecającym rządom tzw. piątej generacji przywódców, na czele z Xi Jinpingiem i premierem Li Keqiangiem, a za jej symboliczny początek w chińskim dyskursie politycznym uznaje się 29 listopada 2012 r., kiedy to przewodniczący Xi w pierwszym wystąpieniu po XVIII zjeździe Komunistycznej Partii Chin (KPCh) bezpośrednio nawiązał do chińskiej wersji słynnego American Dream (Góralczyk, 2016/2017, ss. 288-291).

Mimo że w tytule recenzowanej monografii wyraźnie zawierają się granice przedmiotowe i temporalne pola badawczego, w obszernym rozdziale wprowadzającym zabrakło wzmianki o historycznym przemówieniu Przewodniczącego ChRL z listopada 2012 r. Choć informacje o sa- 
mym przemówieniu, jego treści i implikacjach pojawiły się na kartach kolejnych rozdziałów (m.in. na ss. 24, 51 i 172), książkę wzbogaciłoby choćby skrótowe omówienie podstawowych pojęć charakterystycznych dla „ery Xi Jinpinga” i zaprezentowanie relacji między nimi. $Z$ drugiej strony należy podkreślić, że redaktorzy tomu przygotowali interesujący wywód dotyczący znaczenia tytułowego „renesansu” dla przyszłości zarówno państwa, jak i społeczeństwa chińskiego, wyróżniając najważniejsze wyzwania, z którymi będą musiały zmierzyć się Chiny w trzeciej dekadzie XXI w. Swoje uwagi zaprezentowali w mającym charakter wstępu rozdziale zatytułowanym 'National Rejuvenation' as Panacea for China's Domestic and External Challenges, w którym wyraźnie określili również cele, jakie spełniać ma monografia, ogniskujące się wokół „próby przyjrzenia się zasadom i celom nakreślonym przez $\mathrm{KPCh} w$ procesie dążenia do realizacji renesansu narodu chińskiego [...], poprzez zbadanie szeregu kwestii związanych ze strukturami zarządzania Chinami i rozwojem gospodarczym, po politykę wojskową i zagraniczną wobec państw sąsiednich i całego świata” (tłum. M.D.; s. 12).

Kolejny ważny element metodologiczny, który - w założeniu redaktorów naukowych - ma wyróżniać recenzowany tom z coraz liczniejszej grupy książek poświęconych wybranym aspektom rozwoju współczesnych Chin, to dobór autorów rozdziałów składających się na monografię. Choć przez zaproszenie do współpracy badaczy z Chin, Indii, Malezji i Wietnamu redaktorom udało się uzyskać deklarowaną we wstępie „wyraźnie azjatycką” perspektywę (s. 12), można postawić uzasadnione pytanie, czy ograniczenie się tylko do perspektyw prezentowanych przez naukowców z wymienionych czterech państw nie odbyło się ze szkodą dla książki. Wątpliwości te ogranicza lektura monografii, pozwalająca zauważyć, że mimo wątpliwości co do reprezentatywności autorów (z 14 badaczy siedmioro reprezentuje wietnamskie ośrodki naukowe, pięcioro - indyjskie i po jednym - chińskie i malezyjskie), są to eksperci o uznanym dorobku, których zainteresowania naukowe pokrywają się $\mathrm{z}$ treściami prezentowanymi $\mathrm{w}$ ramach przygotowanych przez nich rozdziałów.

$\mathrm{Na}$ recenzowaną publikację składa się pięć części - rozdział wprowadzający i cztery rozdziały poświęcone kwestiom takim jak: sprawy wewnętrzne, polityka wobec sąsiadów, propaganda KPCh poza granicami kraju oraz rozwój gospodarczy i polityka zagraniczna. Atuty wynikające z wyodrębnienia kwestii istotnych i potencjalnie interesujących dla czytelnika nie zmieniają faktu, że struktura monografii sprawia wrażenie uporządkowanej, jednak nie do końca przemyślanej. W części trzeciej zaprezentowano wybrane aspekty (głównie z zakresu gospodarki i bezpieczeństwa) polityki zagranicznej Chin wobec Azji Południowej, Południowo-Wschodniej, Indo-Pacyfiku i Azji Północno-Wschodniej. Pomijając kwestię braku rozdziału dotyczącego Azji Centralnej, uzasadnione wydaje się pytanie o przyczyny wyodrębnienia części piątej. w zaproponowanym kształcie. Lektura rozdziałów składających się na tę część prowadzi do wniosku, że opisują one jedynie wycinki problematyki, które - bez uzupełnienia o bardziej kompleksową wiedzę na temat chińskich reform gospodarczych i programów realizowanych przez Chiny na świecie, choćby przez Inicjatywę Pasa i Szlaku (Yi dai, Yi lu - nie pozwalają na zrozumienie zależności między przyjętym przez ChRL modelem rozwojowym a kierunkami realizowanej przez państwo polityki 
zagranicznej. Oddzielenie kwestii ekonomicznych od polityki zagranicznej wydaje się zatem zabiegiem niezasadnym.

Istotnym mankamentem książki wydaje się fakt, że mimo powoływania się autorów większości rozdziałów (10 z 15) na źródła chińskojęzyczne, nie jest to w monografii normą. Brak odwołań do oryginalnych źródeł jest szczególnie widoczny w rozdziałach IV. i V. (odpowiednio Xi Jinping's Political and Economic Initiatives and the 'Success Trap' i Political Considerations in the Chinese Leadership's Economic Assessments), których autorzy podjęli się analizy wybranych aspektów polityki wewnętrznej, rezygnując $\mathrm{z}$ uzupełnienia wywodu o chiński dyskurs naukowy i polityczny i ograniczając się do prezentacji komunikatów opublikowanych głównie w prasie anglojęzycznej lub tłumaczonych na język angielski wydaniach „People’s Daily” i komunikatach agencji „Xinhua”.

Wymienione w tej recenzji krytyczne uwagi nie zmieniają faktu, że książka pt. China's Search for 'National Rejuvenation'. Domestic and Foreign Policies under Xi Jinping to warte uwagi studium zasad i celów chińskiej drogi do „renesansu”, zaprezentowane $\mathrm{z}$ wykorzystaniem różnych perspektyw i z uwzględnieniem szeregu kryteriów, zarówno o charakterze wewnętrznym, jak i międzynarodowym. Kwestie przedstawione w monografii z pewnością nie wy- czerpują tematu, jednakże stanowią cenny wkład nie tylko do dyskusji na temat przyszłości koncepcji zainicjowanych przez przewodniczącego Xi Jinpinga, ale także w szerszym ujęciu - przyszłości Chin i ich roli we współczesnym świecie. Braki merytoryczne i uchybienia metodologiczne, od których nie jest wolny recenzowany tom, zostały przez autorów poszczególnych rozdziałów zrekompensowane zastosowaniem oryginalnego podejścia badawczego, odważnymi tezami i klarownym wywodem. Wszystko to sprawia, że China's Search for 'National Rejuvenation' jest książką mogącą zainteresować nie tylko badaczy i pasjonatów Chin, ale i szersze grono czytelników, $\mathrm{w}$ tym przede wszystkim osoby interesujące się przemianami zachodzącymi we współczesnym świecie.

\section{Bibliografia:}

Góralczyk, B. (2016/2017). Geostrategia Xi Jinpinga - Chiny ruszają w świat. Rocznik Strategiczny, 22, 286-300. DOI: 10.7366/ 12300265420152119 .

Góralczyk, B. (2021). Chiński system polityczny - sui generis. W: H. Kupś, M. Szatkowski, M. Dahl (red.). 70 lat Chińskiej Republiki Ludowej w ujęciu interdyscyplinarnym (ss. 13-30). Warszawa: Wydawnictwo Akademickie Dialog. 